$2-2018$

\title{
Curve Number Approach to Estimate Monthly and Annual Direct Runoff
}

\author{
Andrew John Guswa \\ Smith College, aguswa@smith.edu \\ Perrine Hamel \\ Stanford University \\ Kate Meyer \\ University of Minnesota
}

Follow this and additional works at: https://scholarworks.smith.edu/egr_facpubs

Part of the Engineering Commons

\section{Recommended Citation}

Guswa, Andrew John; Hamel, Perrine; and Meyer, Kate, "Curve Number Approach to Estimate Monthly and Annual Direct Runoff" (2018). Engineering: Faculty Publications, Smith College, Northampton, MA.

https://scholarworks.smith.edu/egr_facpubs/15

This Article has been accepted for inclusion in Engineering: Faculty Publications by an authorized administrator of Smith ScholarWorks. For more information, please contact scholarworks@smith.edu 


\title{
Curve number approach to estimate monthly and annual direct runoff
}

\author{
Andrew J. Guswa ${ }^{1}$, Perrine Hamel $^{2}$, Kate Meyer $^{3}$
}

\section{Abstract}

This paper establishes a novel approach to estimate monthly and annual direct runoff by combining the curve number method of the Natural Resources Conservation Service with an exponential distribution of rainfall depths. The approach was tested against observed rainfall and runoff for 544 watersheds throughout the contiguous United States. For more than half of the watersheds, the performance of the new approach is indistinguishable from the application of the method to daily rainfall when curve numbers are determined via calibration. For all watersheds, the uncertainty introduced by the approximation of the distribution of rainfall depths is far less than the uncertainty associated with the use of tabulated curve numbers based on soil and landcover characteristics. The new approach does not appreciably increase the overall uncertainty associated with the application of the curve number method in ungaged watersheds. The approach provides reasonable estimates of monthly and annual direct runoff that can inform land-management decisions when daily rainfall records are unavailable.

${ }^{1}$ Corresponding author, Picker Engineering Program, Smith College, Northampton, MA 01063, aguswa@smith.edu

${ }^{2}$ Natural Capital Project, Stanford University, Stanford, CA 94305

${ }^{3}$ Department of Mathematics, University of Minnesota, Minneapolis, MN 55455

Guswa et al. 
Introduction

23 Changes to the landscape affect many hydrologic processes and ecosystem services (Daily 1997;

24 National Research Council 2004; Martin-Ortega et al. 2015). Estimates of those effects, even 25 when uncertain, benefit land-management decisions. With respect to water resources, effects of 26 interest include changes to total streamflow, to flooding potential, and to the availability of 27 baseflow at monthly to annual and multi-annual timescales (Brauman et al. 2007; Guswa et al. 28 2014; Bremer et al. 2016; Ouyang et al. 2016). Some decisions may require a precise and 29 detailed analysis. Other contexts may tolerate greater uncertainty in order to reduce the time and 30 resources required; these include land-management decisions in ungaged and data-poor locales, 31 or rapid assessments across many ecologic and hydrologic processes that may be followed up by 32 more detailed studies.

The Natural Resources Conservation Service (NRCS) curve number method estimates the

34 direct runoff that results from an individual rainfall event as a function of land cover and soil 35 characteristics (Natural Resources Conservation Service 2004a,b). The concepts have been 36 incorporated into many popular hydrologic models, such as HEC-HMS (U.S. Army Corps of 37 Engineers 2000), SWMM (Rossman 2007), HydroCAD (HydroCAD Software Solutions LLC 38 2011), SWAT (Neitsch et al. 2011), WinTR-20 (Natural Resources Conservation Service 2015), 39 and the InVEST seasonal water yield model (Sharp et al. 2016). The method also has a number 40 of known challenges (Ponce and Hawkins 1996; Hawkins et al. 2009). Specifically, not all 41 watersheds exhibit the asymptotic approach to a constant curve number (Hawkins 1993), curve 42 numbers determined from rainfall-runoff data show significant variability (Hjelmfelt 1991; Shaw 43 and Walter 2009; Hawkins et al. 2009), use of tabulated curve numbers in ungaged watersheds is 44 highly uncertain (Titmarsh et al. 1995; Hawkins et al. 2009; Tedela et al. 2012), and the method 
45 is misused and misapplied (Walter and Shaw 2005; Ogden and Stallard 2013). Despite these

46 challenges, Hawkins et al. (2009) recognize the potential for the curve number method to inform 47 land-management decisions.

48 This study extends the application of the curve number method for land-management

49 decisions when the uncertainty of the event-based method is tolerable but rainfall event data are

50 unavailable. This investigation tests whether direct runoff accumulated over a month or year can

51 be estimated, without an appreciable increase in the uncertainty, by approximating the

52 distribution of actual rainfall depths with an exponential distribution. Rather than requiring a full

53 description of event-by-event precipitation, this new approach requires only total rainfall and an

54 estimate of the number of events over the defined period of interest. The sections that follow

55 explain this new approach and present results from tests on 544 U.S. watersheds.

\section{Curve number method applied to event rainfall}

57 The curve number method estimates the depth of direct runoff from a specified rainfall event 58 (NRCS 2004b). Direct runoff refers to the water that reaches a stream quickly without 59 specification of the pathway or origin of that water (Hawkins et al. 2009). For a given rainfall 60 depth, $P_{i}$, the depth of direct runoff, $Q_{i}$, is calculated as

$$
Q_{i}=g\left(P_{i} ; C N\right)=\left\{\begin{array}{cc}
\frac{\left(P_{i}-\lambda S\right)^{2}}{\left(P_{i}+(1-\lambda) S\right)} & P_{i}>\lambda S \\
0 & P_{i} \leq \lambda S
\end{array}\right.
$$

61 where the subscript $i$ refers to an individual event, $S$ is maximum potential retention with

62 dimensions of depth, and $\lambda S$ is the rainfall depth needed to initiate runoff, also called the initial

63 abstraction. The maximum potential retention, $S$, is related to the curve number, $C N$, an 64 empirical quantity that depends on land use and soil characteristics (NRCS 2004a,b): 


$$
\begin{array}{ll}
S=\frac{1000}{C N}-10 & \text { (S in inches) } \\
S=\frac{25400}{C N}-254 & \text { (S in millimeters) }
\end{array}
$$

In application, curve numbers are either calibrated to rainfall-runoff data or estimated

66 from land-use and soil characteristics when streamflow data are unavailable (NRCS 2004a,b;

67 Hawkins et al. 2009). Both cases require a choice for $\lambda$. The National Engineering Handbook

68 indicates a value of 0.2 for $\lambda$, and tabulated values of curve numbers for different hydrologic soil

69 groups and land covers are based on this value (NRCS 2004a,b). Recent results, however,

70 indicate a smaller value of $\lambda$, closer to 0.05 (Jiang 2001; Hawkins et al. 2009; Shaw and Walter

71 2009; Dahlke et al. 2012). This study uses $\lambda=0.05$. Using that value requires a modification of

72 the curve numbers given in the handbook tables, and Jiang (2001) provides the following 73 relationship:

$$
C N_{0.05}=0.0054 \cdot\left(C N_{0.2}\right)^{2}+0.46 \cdot C N_{0.2}
$$

74 where $C N_{0.2}$ represents a tabulated curve number developed under the presumption that $\lambda=0.2$

75 and $C N_{0.05}$ represents the curve number for use with $\lambda=0.05$.

While the curve number method and tabulated values were developed to estimate runoff

77 from large events, the method has been applied to a wide range of event magnitudes (Hawkins et

78 al. 2009). Hawkins (1993), however, showed that estimates of curve numbers derived from

79 rainfall and runoff data vary with event depth; curve numbers are typically larger for smaller

80 events and approach constant values for larger events, though there are exceptions (e.g., Tedela

81 et al. 2012). Thus, an estimate of runoff for a single, small event could have a large relative

82 error. Runoff accumulations over multiple events, however, are dominated by large events, and

83 the non-linearity of Eq. (1) represents this phenomenon. For example, the MacLeish Field 
84 Station in West Whately, MA experienced seven rain events between 3 June and 27 June 2009

85 with magnitudes of 3.6, 4.0, 8.4, 11.2, 22.9, 38.6, and $58.7 \mathrm{~mm}$ (Guswa and Spence 2011).

86 Applying Eq. (1) to each event, with a curve number appropriate for pasture $\left(C N_{0.05}=59\right)$, gives

87 runoff estimates of $0.0,0.0,0.0,0.0,1.0,4.3$, and $11.0 \mathrm{~mm}$, respectively. Over $93 \%$ of the total

$8816.4 \mathrm{~mm}$ of runoff is generated by the two largest events, and the contribution of the small events

89 to the total error in accumulated runoff is small. Consequently, when event data are available,

90 accumulated runoff over a longer time period $\left(Q_{N}\right)$ can be estimated by direct application of the

91 curve number method to $n$ events over a period of $N$ days,

$$
Q_{N}=\sum_{i=1}^{n} Q_{i}
$$

\section{Curve number approach for monthly and annual runoff}

93 This study presents an approach to estimate monthly and annual direct runoff when rainfall data

94 are not available. This approach requires a tabulated curve number based on landscape

95 characteristics (NRCS 2004a), total rainfall $\left(P_{N}\right)$ over the period of interest ( $N$ days), and an

96 estimate or measurement of either the mean event depth $(\alpha)$ or the frequency $(\eta)$ of rainfall

97 events (events per day). This new approach approximates the actual distribution of rainfall

98 depths with an exponential distribution,

$$
f(p)=\frac{1}{\alpha} \exp \left(-\frac{p}{\alpha}\right)
$$

99 where $p$ is rainfall depth and $\alpha$ is the mean event depth, which can be estimated as

$$
\alpha=\frac{P_{N}}{\eta N}
$$


100 The exponential distribution is a recognized model of rainfall depths (e.g., Eagleson 1978;

101 Richardson 1981; Rodriguez-Iturbe et al. 1999; Laio et al. 2001). Additionally, the exponential 102 distribution is fully characterized by a single parameter, mean rain depth, making it useful in 103 applications with limited data.

104 Combining event-based runoff (Eq. 1) with an exponential distribution of rainfall depths 105 gives an expression for the mean runoff per event from the new approach,

$$
\left\langle Q^{\text {new }}(\alpha ; C N)\right\rangle=\int_{-\infty}^{\infty} g(p ; C N) \cdot f(p ; \alpha) d p
$$

106 where angle brackets indicate expected value. Substituting Eqs. (1) and (6) into (8) gives

$$
\left\langle Q^{\text {new }}\right\rangle=\int_{\lambda S}^{\infty} \frac{(p-\lambda S)^{2}}{(p+(1-\lambda) S)} \cdot \frac{1}{\alpha} \exp \left(-\frac{p}{\alpha}\right) d p
$$

107 Solving Eq. (9) results in the following expression for the mean runoff:

$$
\left\langle Q^{\text {new }}\right\rangle=(\alpha-S) \exp \left(-\frac{\lambda S}{\alpha}\right)+\frac{S^{2}}{\alpha} \exp \left(\frac{(1-\lambda) S}{\alpha}\right) E_{1}\left(\frac{S}{\alpha}\right)
$$

108 where $E_{l}(x)$ is the exponential integral (Abramowitz and Stegun 1972),

$$
E_{1}(x)=\int_{x}^{\infty} \frac{\exp (-u)}{u} d u
$$

109 Cumulative runoff over the period of interest is

$$
Q_{N}^{\text {new }}=\left\langle Q^{\text {new }}\right\rangle \eta N
$$

110 The strength of this new approach lies in its approximation of the distribution of large events.

111 For the earlier example of seven rainfall events $(3.6,4.0,8.4,11.2,22.9,38.6$, and $58.7 \mathrm{~mm})$, 112 event-by-event application of Eq. (1) results in an estimate of $16.4 \mathrm{~mm}$ of total runoff $\left(C N_{0.05}=\right.$ 113 59). If Eq. (1) were applied directly to the mean rainfall depth of $21.1 \mathrm{~mm}$, the estimate of 
114 cumulative runoff from seven such events would be just $5.6 \mathrm{~mm}$; if Eq. (1) were applied directly

115 to the total $147.4 \mathrm{~mm}$ of rainfall, estimated runoff would be $61.0 \mathrm{~mm}$. Application of the new 116 approach with an exponential distribution of depths results in an estimate of cumulative runoff of

$11717.4 \mathrm{~mm}$, very close to the $16.4 \mathrm{~mm}$ estimated by application of the curve number method to 118 each event individually.

\section{Evaluation of new approach}

\section{Rainfall and runoff for U.S. watersheds}

121 To test the new approach, this work used a dataset of daily meteorology and streamflow for 671 122 watersheds throughout the contiguous United States (Newman et al. 2014; Newman et al. 2015).

123 Watersheds range in size from 1 to $25000 \mathrm{~km}^{2}$, with a median size of $335 \mathrm{~km}^{2}$ and two-thirds of

124 the watersheds between 100 and $1000 \mathrm{~km}^{2}$ (Newman et al. 2015). Streamflow data are from the 125 U.S. Geological Survey and the Daymet dataset is the source of meteorological data (Newman et 126 al. 2015). The dataset includes precipitation and streamflow records from $1 / 1 / 1980$ through

$12712 / 31 / 2010$. Some of the records were eliminated or modified for this analysis after quality 128 assurance checks; Appendix A includes details.

129 Runoff and baseflow were computed for two time scales of analysis: monthly and annual.

130 Because the curve number method is not appropriate for snowmelt, analyses were limited to 131 snow-free months and years. For the monthly analysis of each watershed, this study eliminated 132 all months for which the snow-water equivalent was non-zero for some time during the month.

133 Similarly, for the annual analysis, all years that were influenced by snow were removed. To 134 ensure an adequate sample size of monthly runoff values for each watershed, monthly analyses 135 were restricted to watersheds with more than ten months (total, not per year) of snow-free 
136 observations, and annual analyses were limited to watersheds with more than ten years of snow-

137 free observations. Figure 1 presents a map of the watersheds used to test the approaches. Open 138 circles represent watersheds included in the monthly analysis; filled circles represent watersheds

139 included in both monthly and annual analyses.

140 Daily streamflow was separated into baseflow and direct runoff with a one-parameter 141 recursive digital filter (Nathan and McMahon 1990) with a filter parameter of 0.925. This 142 automated method of baseflow separation is objective, repeatable, and gives results similar to the 143 smoothed minima method (Nathan and McMahon 1990). Summing direct runoff over each

144 month and year produced records of observed monthly $\left(Q_{m}{ }^{o b s}\right)$ and annual $\left(Q_{a}{ }^{o b s}\right)$ direct runoff 145 for each watershed.

\section{Curve numbers determined from daily records}

147 The objective of this investigation is to test whether the accumulated runoff estimated by using 148 an exponential distribution of rainfall depths is equivalent to that determined by applying the 149 curve number method directly to a record of daily rainfall depths. To separate the uncertainty 150 introduced by the use of tabulated curve numbers from the uncertainty due to the approximation 151 of the rainfall distribution, a curve number for each watershed was determined through 152 calibration. Consistent with the intent of estimating accumulated runoff, the curve number for 153 each watershed was determined by matching the cumulative direct runoff, estimated by applying 154 the curve number to daily rainfall, to the cumulative observed runoff over the entire period of 155 record. This calibration ensures that the average bias in the daily application of the curve 156 number method is zero, i.e., the mean error between observed (monthly or annual) runoff and the 157 runoff estimated by application of the curve number method to daily rainfall is zero. 
158 Accumulated runoff is dominated by large events, and the largest events of the period of record

159 strongly influence the calibration of the curve number.

160 With a calibrated curve number for each watershed, this study applied Eq. (1) to daily

161 rainfall to compute daily runoff, which was then summed to create records of monthly and

162 annual direct runoff. Monthly and annual errors were quantified by taking the difference

163 between the monthly and annual estimates and observations:

$$
\begin{aligned}
& \varepsilon_{m}^{\text {daily }}=\left(Q_{m}^{\text {daily }}-Q_{m}^{o b s}\right) \\
& \varepsilon_{a}^{\text {daily }}=\left(Q_{a}^{\text {daily }}-Q_{a}^{o b s}\right)
\end{aligned}
$$

164 where $Q_{m}^{\text {daily }}$ and $Q_{a}^{\text {daily }}$ represent the monthly and annual direct runoff, respectively, estimated

165 by applying the curve number method to daily rainfall. By design, the mean values of $\varepsilon_{m}^{\text {daily }}$ and $166 \varepsilon_{a}^{d a i l y}$ are zero for each watershed, as noted previously.

\section{Application of the new approach}

168 In the new approach, the actual, empirical distribution of daily rainfall depths is replaced with an

169 exponential distribution, defined by a mean event depth, $\alpha$, for each month or year. This average

170 depth was calculated in two ways. One variation computed the mean rainfall depth by dividing

171 the cumulative rainfall by the actual number of days with rain in each month or year. A second

172 variation evaluated the utility of the new approach when information on number of events is

173 approximate. In the monthly application, mean rainfall depth was computed with the average

174 number of events for that month over all years in the dataset for that watershed (for example, the

175 average number of events for all Septembers). Similarly, the average number of events per year

176 was used in the annual application. The resulting two variations of the exponential distributions

177 were used with calibrated curve numbers in Eqs. (10-12) to estimate monthly and annual runoff 
178 for each watershed. Thus, each watershed is associated with four records of monthly (and

179 annual) runoff: observed runoff, runoff estimated by application of the curve number method to 180 daily rainfall, runoff estimated from an exponential distribution of rain depths with mean rainfall

181 depth determined by the actual number of events in each month (and year), runoff estimated

182 from an exponential distribution of rain depths with mean rainfall depth determined by the 183 average number of events.

184 Tests of the new approach

185 Both across watersheds and for each individual watershed, this study evaluated the performance 186 of the new monthly and annual approaches by assessing 1) the mean error in monthly and annual 187 runoff relative to observations, 2) the difference in squared errors of monthly and annual runoff 188 between the new approach and the application of the curve number method to daily rainfall, and 1893 3) the error in runoff relative to the uncertainty attributed to the use of tabulated curve numbers 190 in ungaged watersheds. The descriptions that follow refer to monthly runoff, and the same tests 191 apply to annual estimates as well. All tests were restricted to months (and years) with non-zero 192 observed direct runoff.

193 The first tests assessed the mean error between observations and estimates from the new 194 approach. A non-parametric bootstrap technique (Efron and Tibshirani 1993) was used to test 195 the null hypothesis that the mean error in monthly runoff is indistinguishable from zero. 196 Sampling (with replacement) the $m$ monthly errors $m$ times for all months and all watersheds 197 generated a bootstrap estimate of the mean error. This process was repeated to generate 10000 198 estimates of the mean error. A 95\%-confidence interval for the mean error in monthly runoff 199 was created from the $2.5 \%$ and $97.5 \%$ quantiles of the bootstrap estimates. The null hypothesis 
200 that the mean error is indistinguishable from zero was accepted if the confidence interval

201 contained zero. Estimates of the mean monthly runoff were also regressed against the observed 202 means for all watersheds. To assess the mean error for each individual watershed, 10000 203 bootstrap estimates of the mean error were generated by sampling (with replacement) the $M$ 204 months of errors $M$ times for each watershed. A 95\%-confidence interval for the mean error was 205 created from the $2.5 \%$ and $97.5 \%$ quantiles of the bootstrap estimates.

206 Even when Eq. (1) is applied to daily data and curve numbers are calibrated to ensure no 207 bias in the mean monthly runoff, model structural error leads to uncertainty in estimated runoff 208 for any given month. Approximating the rainfall depths with an exponential distribution further 209 increases this uncertainty. While it is desirable for monthly errors in the new approach to be 210 small, more important for this study is to test whether the errors from the new approach are 211 comparable to those from the application of the curve number method to daily rainfall, i.e., to 212 test whether the additional error due to the exponential approximation is small relative to the 213 structural error of the curve number method. For each watershed, the square of the error between 214 estimated and observed monthly runoff was determined, and the difference in squared-error 215 between the daily method and the new approach computed:

$$
\Delta_{m}^{s e}=\left(Q_{m}^{\text {new }}-Q_{m}^{o b s}\right)^{2}-\left(Q_{m}^{\text {daily }}-Q_{m}^{o b s}\right)^{2}
$$

216 This statistic is positive when the squared error in monthly runoff is larger for the new approach 217 and negative when the error is larger for the daily application. To test whether the mean of 218 squared errors from the new approach are significantly larger than those from the daily 219 application of the curve number, 10000 bootstrap samples of the mean difference in squared220 error were generated. The null hypothesis that the error of the new approach is no larger than the 221 error in the daily method (one-sided test) was rejected if the 5\%-quantile of the mean difference 
222 in squared error was greater than zero. A linear regression of the square root of the mean-

223 squared error (RMSE) from the new approach to the RMSE from the daily application of the 224 method quantified the difference in uncertainty between the approaches.

225 A third test compared the mean error in runoff estimates with the uncertainty due to the

226 use of tabulated curve numbers for ungaged basins. Tabulated curve numbers are a function of

227 land-cover and soil characteristics and are reported for average antecedent runoff conditions,

228 ARC II (NRCS 2004a). Titmarsh (1995) and Hawkins and Ward (1998, reproduced and cited in

229 Hawkins et al. 2009) showed that the uncertainty in using tabulated curve numbers is large and

230 comparable to the envelope of uncertainty created by using curve numbers that correspond to

231 antecedent runoff conditions ARC I and ARC III (NRCS 2004b). Hjelmfelt (1991) showed that

232 this envelope created by ARC I and ARC III represents the $10 \%$ and $90 \%$ exceedance

233 probabilities for runoff. Runoff estimates from the new approach were tested against this

234 envelope of uncertainty that resulted from the application of Eq. (1) to daily rainfall with curve

235 numbers corresponding to ARC I and III for the calibrated curve numbers.

\section{Results}

237 Removing months and years with snow from the analyses left 544 watersheds with more than ten 238 months of monthly runoff observations and 97 watersheds with more than ten years of annual

239 data (Fig. 1). The total number of observations of monthly runoff across all watersheds and all 240 months is 127927 ; the number of total observations of annual runoff is 2270 . Estimates of mean

241 monthly runoff from the new approach show good agreement with the observed runoff (Fig. 2).

242 Though the mean errors are statistically different from zero (95\% confidence), they are small: 1.2

$243 \mathrm{~mm} / \mathrm{month}$ and $2.9 \mathrm{~mm} / \mathrm{month}$ for use of the actual and average number of events, respectively

244 (Table 1). The regression slopes of 1.11 to 1.20 indicate that the estimated mean monthly runoff 
245 is approximately $10-20 \%$ greater than observed (Table 1 and Fig. 2). Considering each 246 watershed separately, the error in mean monthly runoff is indistinguishable from zero $(95 \%$ 247 confidence interval) for $65 \%$ of the 544 watersheds when the actual number of rain events is 248 used in the new approach (Table 2). When the average number of events per month is used, the 249 error in mean monthly runoff is indistinguishable from zero (95\%-confidence interval) for $26 \%$ 250 of the 544 watersheds. For both monthly approaches, estimates of mean monthly runoff for all $251(100 \%)$ of the 544 watersheds fall within the envelope of uncertainty associated with using 252 tabulated curve numbers (x's in Figure 2).

253 The RMSE of monthly runoff for the application of the calibrated curve number method 254 to daily rainfall quantifies the structural error of the method. Fig. 3 indicates that this structural 255 error is increased only slightly by the introduction of the exponential approximation. Regression 256 slopes of 1.02-1.10 indicate that the RMSE of monthly runoff determined via the new approach 257 is approximately $5-10 \%$ larger than the RMSE for monthly runoff determined via application of 258 the curve number method to daily data (Table 1 and Figure 3). Mean monthly errors from the 259 approach using the average number of events per month are larger than those from the approach 260 that uses the actual number of events. The paired test of differences in monthly squared errors 261 (Eq. 15) found that monthly squared errors from the new approach are not significantly larger 262 than the errors from the daily application of the curve number method for $80 \%$ and $65 \%$ of the 263 watersheds (actual and average number of events, respectively, 95\%-confidence, 1-sided test, 264 Table 2).

265 Tables 1 and 2 and Figs. 4 and 5 present results for the annual approaches. Fig. 4 266 indicates a good match in annual runoff between the new approach and observations. The mean 267 errors in annual runoff are statistically different from zero ( $95 \%$ confidence, Table 1), and they 
268 are small: $10 \mathrm{~mm} /$ year and $8 \mathrm{~mm} /$ year for use of the actual and average number of events,

269 respectively. Across the watersheds, mean annual runoff estimated via the new method is 270 approximately 7\% less than observed, as evidenced by a regression slope of 0.93 (Table 1).

271 Mean error in annual runoff is indistinguishable from zero for $64 \%$ (actual number of events)

272 and $65 \%$ (average number of events) of watersheds. Errors in annual estimates of direct runoff

273 with the new approach are comparable to the errors associated with employing the curve number

274 method to daily data (Fig. 5). The RMSE of annual runoff determined via the new approach is

275 approximately $4 \mathrm{~mm}$ larger than the RMSE of annual runoff determined via application of the

276 curve number method to daily data, indicated by regression slopes of 1.0 and intercepts of $4 \mathrm{~mm}$

277 (Table 1 and Fig. 5). The paired tests indicate that squared errors from the new approach are not

278 significantly larger than the errors from the daily application of the curve number method for

$27974 \%$ and $88 \%$ of the watersheds (actual and average number of events, respectively, 95\%-

280 confidence, 1-sided test). Estimates of mean annual runoff for all (100\%) of the 97 watersheds

281 fall within the uncertainty envelope associated with use of tabulated curve numbers (x's in Fig. $2824)$.

\section{Discussion}

284 Figs. 2-5 indicate that the new approach presented in this work estimates monthly and annual 285 direct runoff with a similar degree of certainty as the application of the curve number method to 286 daily data for ungaged watersheds. The overestimation of runoff in the monthly results (Fig. 2 287 and Table 1) may indicate a deviation from the simplification of an exponential distribution of 288 rainfall events. If actual rain events within a month are more similar to each other, i.e., if the 289 empirical distribution has a smaller variance than the exponential, then the approach based on the 290 exponential distribution would overestimate runoff, consistent with what is seen in Fig. 2. 
291 Month-to-month and year-to-year errors in estimates from the new approach are similar to errors

292 from the application of the curve-number method to daily rainfall (Tables 1 and 2 and Figs. 3 and

293 5). Most importantly, mean monthly and annual estimates of direct runoff lie well within the

294 confidence interval attributed to uncertainty in the curve number (Figs. 2 and 4). This is

295 consistent with earlier findings that estimated runoff is more sensitive to the selection of the 296 curve number than to the precipitation depth (Hawkins 1975) and indicates that the

297 approximation of an exponential distribution of rainfall depths does not appreciably increase the 298 uncertainty associated with the application of the curve number method in ungaged watersheds.

299 The large uncertainty in estimates of monthly and annual runoff for ungaged watersheds suggests 300 that runoff estimates should be used with care.

301 While the new approach does not require daily rainfall data, it does require an estimate of 302 the number of rain events within a given period of interest. Tables 1 and 2 and Figs. 2-5 indicate 303 that estimates based on an average number of events are almost as good as those that use the 304 actual number of events. Local estimates of the number of rain events could be obtained from 305 traditional knowledge, global precipitation datasets (e.g., Gehne et al. 2016; The World Bank 306 Group 2016), or historical records.

307 Many monthly (and annual) water-balance models have as a first step the partitioning of 308 precipitation into direct runoff and retention (e.g., Ponce and Shetty 1995; Zhang et al. 2008;

309 Sivapalan et al. 2011; Kirby et al. 2013; Chen and Wang 2015). These incorporate a relationship

310 between monthly rainfall and direct runoff as a function of landscape characteristics (such as

311 slope, soil type, land use) and state variables of the system (such as soil moisture and 312 streamflow). The approach presented here provides a means for estimating or eliminating model 313 parameters in these models. For example, the Dynamic Water Balance Model (DWBM; Zhang 
314 et al. 2008), relies on a parameter, $\alpha_{1}$, to partition monthly precipitation into direct runoff and

315 retention. This parameter must generally be determined via calibration, as attempts to relate the

316 parameter to measurable watershed characteristics have proved challenging (Zhang et al. 2017).

317 The approach presented here, with knowledge of the curve number and typical number of

318 precipitation events, is another way to determine the amount of direct runoff from monthly

319 precipitation.

320 Estimates of annual runoff from this new approach enable the partitioning of annual

321 streamflow into direct runoff and baseflow. For example, a Budyko-type approach can estimate

322 average annual streamflow based on average annual precipitation and potential

323 evapotranspiration (e.g., Budyko 1974; Porporato et al. 2004; Szilagyi and Jozsa 2009; Hamel

324 and Guswa 2015). Based on rainfall data from Monteverde, Costa Rica (Guswa et al. 2007), the

325 Budyko curve predicts an increase in annual streamflow of $160 \mathrm{~mm} / \mathrm{yr}$ following the conversion

326 of forest to pasture (Table 3). The new approach presented in this study complements this result

327 by estimating changes to direct runoff and, by subtraction, baseflow. For two soil groups (B and

328 D), the new approach indicates a decrease in baseflow $(40 \mathrm{~mm} / \mathrm{yr}$ or $210 \mathrm{~mm} / \mathrm{yr}$ for soil groups B

329 and D, respectively), despite the increase in total streamflow. The large uncertainty associated

330 with using a tabulated curve number (characterized by ARC I and III), however, prevents a

331 definitive statement, as the confidence intervals for the change in baseflow include zero (Table

332 3). Nonetheless, the interpretation that baseflow is more likely than not to decrease when forest

333 is converted to pasture may be sufficient to inform land-management decisions.

\section{Conclusions}

335 This study developed a new approach to estimate monthly and annual direct runoff by combining

336 the NRCS curve number method with an exponential distribution of rainfall depths. Evaluation

Guswa et al.

page 16 of 21 
337 of the approach with daily rainfall and runoff data from 544 U.S. watersheds indicates that the

338 error introduced by the exponential approximation is small and lies well within the uncertainty

339 associated with application of the curve number method in ungaged watersheds. The simplicity

340 and robust performance of the approach indicate that it can inform planning and land-

341 management decisions in data-poor contexts.

\section{Appendix A}

344 Inspection of the dataset provided by Newman et al. (2014) revealed some questionable data. 345 The authors either removed these basins from further analysis or modified the data as indicated 346 in Tables A1-A2 below. In tables A1-A2, $Q$ and $P$ are the average daily streamflow and precipitation as reported in the file basin_annual_hydrometeorology_characteristics_daymet.txt (Newman et al. 2014). The variables, $q$ and $p$, are the average daily streamflow and precipitation calculated from daily values of discharge (U.S. Geological Survey) and precipitation (Daymet), respectively, for each watershed over the entire period of record. For internal consistency, $Q$ should be equal to $q$, and $P$ should be equal to $p$; significant discrepancies were cause for removal of those watersheds from further analysis."

\section{References}

Abramowitz, M. and Stegun, I. A. (1972). Handbook of mathematical functions with formulas, graphs, and mathematical tables. Dover Publications, New York, New York.

Brauman, K., Daily, G. C., Duarte, T. K., and Mooney, H. A. (2007). The nature and value of ecosystem services: An overview highlighting hydrologic services, Annual Review of Environment and Resources, 32, 67-98.

Bremer, L. L., Auerbach, D. A., Goldstein, J. H., Vogl, A. L., Shemie, D., Kroeger, T., Nelson, J. L., Benitez, S. P., Calvache, A., Guimarães, J., Herron, C., Higgins, J., Klemz, C., León, J., Lozano, J. S., Moreno, P. H., Nuñez, F., Veiga, F., and Tiepolo, G. (2016). One size does not fit all: Natural infrastructure investments within the Latin American Water Funds Partnership, Ecosystem Services, 17, 217-236.

Budyko, M. I. (1974). Climate and life, Academic Press, San Diego, California.

Chen, X., and Wang, D. (2015). Modeling seasonal surface runoff and base flow based on the generalized proportionality hypothesis, Journal of Hydrology, 527, 367-379, doi: 10.1016/j.jhydrol.2015.04.059. 
Dahlke, H. E., Easton, Z. M., Walter, M. T., and Steenhius, T. S. (2012). Field test of the variable source area interpretation of the curve number rainfall-runoff equation, Journal of Irrigation and Drainage Engineering, 138(3), 235-244.

Daily, G. C., Ed. (1997). Nature's services: societal dependence on natural ecosystems, Island Press, Washington DC.

Eagleson, P. S. (1978). Climate, soil, and vegetation. 1. Introduction to water balance dynamics. Water Resources Research, 14(5), 705-12.

Efron, B., and Tibshirani, R. J. (1993). An introduction to the bootstrap, Monographs on statistics and applied probability 57, Chapman \& Hall, New York, NY.

Gehne, M., Hamill, T. M., Kiladis, G. N., and Trenberth, K. E. (2016). Comparison of global precipitation estimates across a range of temporal and spatial scales, Journal of Climate, doi:10.1175/JCLI-D-15-0618.1.

Guswa, A. J., Rhodes, A. L., and Newell, S. (2007). Importance of orographic precipitation to the water resources of Monteverde, Costa Rica, Advances in Water Resources, 30, 20982112.

Guswa, A. J., and Spence, C. M. (2011). Effect of throughfall variability on recharge: application to hemlock and deciduous forests in western Massachusetts, Ecohydrology, 5(5), doi: 10.1002/eco.217.

Guswa, A. J., Brauman, K. A., Brown, C., Hamel, P., Keeler, B. L., and Sayre, S. S. (2014). Ecosystem services: Challenges and opportunities for hydrologic modeling to support decision making, Water Resources Research, 50, 4535-4544, doi:10.1002/2014WR015497.

Hamel, P., and Guswa, A. J. (2015). Uncertainty analysis of a spatially explicit annual waterbalance model: case study of the Cape Fear basin, North Carolina, Hydrology and Earth System Sciences, 19, 839-853, doi: 10.5194/hess-19-839-2015.

Hawkins, R. H. (1975). The importance of accurate curve numbers in the estimation of storm runoff. Water Resources Bulletin 11(5), 887-891.

Hawkins, R. H. (1993). Asymptotic determination of curve numbers from data, Journal of Irrigation and Drainage Engineering, 119(2), 334-345.

Hawkins, R. H., Ward, T. J., Woodward, D. E., and Van Mullem, J. A. eds. (2009). Curve number hydrology: State of the practice, American Society of Civil Engineers, Reston, VA.

Hjelmfelt, A. (1991). Investigation of curve number procedure, Journal of Hydraulic Engineering, 117(6), 725-737. 
HydroCAD Software Solutions LLC (2011). HydroCAD Owner's Manual, HydroCAD Software Solutions LLC, Chocorua, NH, 176 pages.

Jiang, R. (2001). Investigation of runoff curve number initial abstraction ratio, M.S. Thesis, School of Renewable Natural Resources, University of Arizona.

Kirby, J. M., Mainuddin, Md., Ahmad, M. D., and Gao, L. (2013). Simplified monthly hydrology and irrigation water use model to explore sustainable water management options in the Murray-Darling Basin, Water Resources Management, 27, 4083-3097, doi:10.1007/s11269013-0397-x.

Laio, F., Porporato, A., Ridolfi, L., and Rodriguez-Iturbe, I. (2001). Plants in water-controlled ecosystems: Active role in hydrologic processes and response to water stress II. Probabilistic soil moisture dynamics, Advances in Water Resources, 24, 707-723.

Martin-Ortega, J., Ferrier, R. C., Gordon, I. J., and Khan, S. (2015). Water ecosystem services: A global perspective, Cambridge University Press, Cambridge, UK.

Nathan, R. J., and McMahon, T. A. (1990). Evaluation of automated techniques for base flow and recession analyses, Water Resources Research, 26(7), 1465-1473.

National Research Council (2004). Valuing ecosystem services: Toward better environmental decision-making. National Academies Press, Washington, DC.

Natural Resources Conservation Service (NRCS, 2004a). Chapter 9, Hydrologic soil-cover complexes, National Engineering Handbook, Part 630 Hydrology, , http://www.wcc.nrcs.usda.gov/ftpref/wntsc/H\&H/NEHhydrology/ch9.pdf accessed on 27 August 2016.

Natural Resources Conservation Service (NRCS, 2004b). Chapter 10, Estimation of direct runoff from storm rainfall, National Engineering Handbook, Part 630 Hydrology, http://www.wcc.nrcs.usda.gov/ftpref/wntsc/H\&H/NEHhydrology/ch10.pdf accessed on 14 March 2016.

Natural Resources Conservation Service (2015). WinTR-20 User Guide, ver 3.10, http://www.wcc.nrcs.usda.gov/ftpref/wntsc/H\&H/WinTR20/WinTR20UserGuideVer310Mar 2015.pdf, accessed on 14 March 2016.

Neitsch, S. L., Arnold, J. G., Kiniry, J. R., and Williams, J. R. (2011). Soil and Water Assessment Tool theoretical documentation ver 2009. Texas Water Resources Institute Technical Report No. 406, http://swat.tamu.edu/media/99192/swat2009-theory.pdf accessed on 14 March 2016.

Newman, A. J., Sampson, K., Clark, M. P., Bock, A, Viger, R. J., and Blodgett, D. (2014). A large-sample watershed-scale hydrometeorological dataset for the contiguous USA. Boulder, CO: UCAR/NCAR. http://dx.doi.org/10.5065/D6MW2F4D. 
Newman, A. J., Clark, M. P., Sampson, K., Wood, A., Hay, L. E., Bock, A., Viger, R. J., Blodgett, D., Brekke, L., Arnold, J. R., Hopson, T., and Duan, Q. (2015). Development of a large-sample watershed-scale hydrometeorological dataset for the contiguous USA: dataset characteristics and assessment of regional variability in hydrologic model performance. Hydrology and Earth System Sciences, 19, 209-223, doi: 10.5194/hess-19-209-2015.

Ogden, F., and Stallard, R. F. (2013). Land use effects on ecosystem service provisioning in tropical watersheds, still an important unsolved problem, Proceedings of the National Academy of Sciences, 110(52), E5037.

Ogden, F. L., Crouch, T. D., Stallard, R. F., and Hall, J. S. (2013). Effect of land cover and use on dry season river runoff, runoff efficiency, and peak storm runoff in the seasonal tropics of Central Panama, Water Resources Research, 49, 8443-8462, doi:10.1002/2013WR013956.

Ouyang, Z., Zheng, H., Xiao, Y., Polasky, S., Liu, J., Xu, W., Wang, Q., Zhang, L., Xiao, Y., Rao, E., Jiang, L., Lu, F., Wang, X., Yang, G., Gong, S., Wu, B., Zeng, Y., Yang, W., and Daily, G. C. (2016). Improvements in ecosystem services from investments in natural capital. Science, 352, 6292, 1455-1459.

Ponce, V. M., and Hawkins, R. H. (1996). Runoff curve number: Has it reached maturity?, Journal of Hydrologic Engineering, 1(1), 11-19.

Ponce, V. M., and Shetty, A. V. (1995). A conceptual model of catchment water balance: 1. Formulation and calibration, Journal of Hydrology, 173, 27-40.

Porporato, A., Daly, E., and Rodriguez-Iturbe, I. (2004). Soil water balance and ecosystem response to climate change, American Naturalist, 164, 625-632.

Richardson, C. W. (1981). Stochastic simulation of daily precipitation, temperature, and solar radiation, Water Resources Research, 17(1), 182-190.

Rodriguez-Iturbe, I., Porporato, A., Ridolfi, L., Isham, V., and Cox, D. (1999). Probabilistic modeling of water balance at a point: The role of climate, soil and vegetation. Proceedings of the Royal Society of London A, 455, 3789-3805.

Rossman, L. A. (2007). Storm water management model user's manual, EPA/600/R-05/040, U.S. Environmental Protection Agency, Cincinnati, OH.

Sharp, R., Tallis, H. T., Ricketts, T., Guerry, A. D., Wood, S. A., Chaplin-Kramer, R., Nelson, E., Ennaanay, D., Wolny, S., Olwero, N., Vigerstol, K., Pennington, D., Mendoza, G., Aukema, J., Foster, J., Forrest, J., Cameron, D., Arkema, K., Lonsdorf, E., Kennedy, C., Verutes, G., Kim, C. K., Guannel, G., Papenfus, M., Toft, J., Marsik, M., Bernhardt, J., Griffin, R., Glowinski, K., Chaumont, N., Perelman, A., Lacayo, M., Mandle, L., Hamel, P., Vogl, A. L., Rogers, L., and Bierbower, W. (2016). InVEST 3.3.0 User's Guide. The Natural Capital Project, Stanford University, University of Minnesota, The Nature Conservancy, and 
World Wildlife Fund. http://www.naturalcapitalproject.org/invest/ accessed on 14 March 2016.

Shaw, S. B., and Walter, M. T. (2009). Improving runoff risk estimates: Formulating runoff as a bivariate process using the SCS curve number method, Water Resources Research, 45, W03404, doi:10.1029/2008WR006900.

Sivapalan, M., Yaeger, M. A., Harman, C. J., Xu, X., and Troch, P. A. (2011). Functional model of water balance variability at the catchment scale: 1. Evidence of hydrologic similarity and space-time symmetry, Water Resources Research, 47, W02522, doi:10.1029/2010WR009568.

Szilagyi, J. and Jozsa, J. (2009). Complementary relationship of evaporation and the mean annual water-energy balance, Water Resources Research, 45, W09201, doi: 10.1029/2009WR008129.

Tedela, N. H., McCutcheon, S. C., Rasmussen, T. C., Hawkins, R. H., Swank, W. T., Campbell, J. L., Adams, M. B., Jackson, C. R., and Tollner, E. W. (2012). Runoff curve numbers for 10 small forested watersheds in the mountains of the eastern United States, Journal of Hydrologic Engineering, 17(11), 1188-1198.

Titmarsh, G. W., Cordery, I., and Pilgrim, D. H. (1995). Calibration procedures for rational and USSCS design flood methods, Journal of Hydraulic Engineering, 121(1), 61-70.

U.S. Army Corps of Engineers (2000). Hydrologic modeling system HEC-HMS, Technical reference manual, US Army Corps of Engineers, Hydrologic Engineering Center, Davis, CA, 155 pages.

Walter, M. T., and Shaw, S. B. (2005). Discussion: "Curve number hydrology in water quality modeling: Uses, abuses, and future directions" by David C. Garen and Daniel S. Moore, Journal of the American Water Resources Association (JAWRA), 41(6), 1491-1492.

Wang, J., and Georgakakos, K. P. (2007). Estimation of potential evapotranspiration in the mountainous Panama Canal watershed, Hydrological Processes, 21, 1901-1917, doi:10.1002/hyp.6394.

World Bank Group (2016). Climate Change Knowledge Portal. Available at: http://sdwebx.worldbank.org/climateportal/

Zhang, L., Potter, N., Hickel, K., Zhang, Y., and Shao, Q. (2008). Water balance modeling over variable time scales based on the Budyko framework - Model development and testing, Journal of Hydrology, 360, 117-131.

Zhang, L., Hickel, K., and Shao, Q. (2017). Predicting afforestation impacts on monthly streamflow using the DWBM model, Ecohydrology, 10(2), doi:10.1002/eco.1821. 


\section{Tables}

Table 1: Assessment of mean error and root-mean-squared error of monthly and annual runoff across watersheds.

\begin{tabular}{|c|c|c|c|c|c|c|}
\hline & & & \multicolumn{2}{|c|}{$\begin{array}{l}\text { Regression of estimated mean } \\
\text { runoff from new approach against } \\
\text { observed (Figs. } 2 \text { and } 4 \text { ) }\end{array}$} & \multicolumn{2}{|c|}{$\begin{array}{l}\text { Regression of RMSE from new } \\
\text { approach against RMSE from daily } \\
\text { method (Figs. } 3 \text { and 5) }\end{array}$} \\
\hline $\begin{array}{l}\text { Temporal } \\
\text { Resolution }\end{array}$ & $\begin{array}{l}\text { Number } \\
\text { of events }\end{array}$ & $\begin{array}{l}\text { Mean error } \\
\text { (observed- } \\
\text { estimated) } \\
\text { and [95\%- } \\
\text { confidence } \\
\text { interval] }\end{array}$ & $\begin{array}{l}\text { Slope } \\
{[95 \% \text { confidence }} \\
\text { interval }]\end{array}$ & $\begin{array}{l}\text { Intercept } \\
{[95 \% \text { confidence }} \\
\text { interval] }\end{array}$ & $\begin{array}{l}\text { Slope } \\
{[95 \% \text { confidence }} \\
\text { interval] }\end{array}$ & $\begin{array}{l}\text { Intercept } \\
{[95 \% \text { confidence }} \\
\text { interval }]\end{array}$ \\
\hline Monthly & Actual & $\begin{array}{c}-1.24 \mathrm{~mm} \\
{[-1.32,-1.16]}\end{array}$ & $\begin{array}{c}1.13 \\
{[1.11,1.14]}\end{array}$ & $\begin{array}{c}-0.3 \mathrm{~mm} \\
{[-0.5,-0.2]}\end{array}$ & $\begin{array}{c}1.03 \\
{[1.02,1.04]}\end{array}$ & $\begin{array}{c}0.04 \mathrm{~mm} \\
{[-0.08,0.16]}\end{array}$ \\
\hline Monthly & Average & $\begin{array}{c}-2.87 \mathrm{~mm} \\
{[-2.95,-2.78]}\end{array}$ & $\begin{array}{c}1.19 \\
{[1.17,1.20]}\end{array}$ & $\begin{array}{c}0.4 \mathrm{~mm} \\
{[0.2,0.6]}\end{array}$ & $\begin{array}{c}1.07 \\
{[1.05,1.10]}\end{array}$ & $\begin{array}{c}0.5 \mathrm{~mm} \\
{[0.13,0.78]}\end{array}$ \\
\hline Annual & Actual & $\begin{array}{l}10 \mathrm{~mm} \\
{[8,13]}\end{array}$ & $\begin{array}{c}0.93 \\
{[0.89,0.97]}\end{array}$ & $\begin{array}{l}-1 \mathrm{~mm} \\
{[-8,6]}\end{array}$ & $\begin{array}{c}1.06 \\
{[0.98,1.13]}\end{array}$ & $\begin{array}{l}4 \mathrm{~mm} \\
{[0,8]}\end{array}$ \\
\hline Annual & Average & $\begin{array}{c}8 \mathrm{~mm} \\
{[6,11]}\end{array}$ & $\begin{array}{c}0.93 \\
{[0.89,0.97]}\end{array}$ & $\begin{array}{l}1 \mathrm{~mm} \\
{[-5,8]}\end{array}$ & $\begin{array}{c}1.00 \\
{[0.92,1.08]}\end{array}$ & $\begin{array}{l}4 \mathrm{~mm} \\
{[-1,8]}\end{array}$ \\
\hline
\end{tabular}


Table 2: Mean error, magnitude of squared error, and mean error versus the uncertainty in curve number for each watershed.

\begin{tabular}{|l|l|l|l|c|}
\hline & & \multicolumn{3}{|c|}{ Percent of watersheds for which } \\
\hline $\begin{array}{l}\text { Temporal } \\
\text { Resolution }\end{array}$ & $\begin{array}{l}\text { Number of } \\
\text { events }\end{array}$ & $\begin{array}{l}\text { Mean error in runoff is } \\
\text { indistinguishable from } \\
\text { zero (95\%-confidence } \\
\text { interval) }\end{array}$ & $\begin{array}{l}\text { Squared error from new } \\
\text { method is less than or } \\
\text { equal to squared error } \\
\text { from daily method } \\
\text { (95\%-confidence } \\
\text { interval, 1-sided) }\end{array}$ & $\begin{array}{l}\text { Mean runoff is within } \\
\text { confidence interval } \\
\text { defined by uncertainty } \\
\text { in CN (ARC I and III) }\end{array}$ \\
\hline Monthly & Actual & $65 \%$ & $80 \%$ & $100 \%$ \\
\hline Monthly & Average & $26 \%$ & $65 \%$ & $100 \%$ \\
\hline Annual & Actual & $64 \%$ & $88 \%$ & $100 \%$ \\
\hline Annual & Average & $65 \%$ & & $100 \%$ \\
\hline
\end{tabular}


Table 3: Example of conversion of forest to degraded pasture. Rainfall data are representative of Monteverde, Costa Rica: 2700 $\mathrm{mm} / \mathrm{yr}$ and 280 events/year (Guswa et al. 2007); potential evapotranspiration is representative of tropical forest and pasture (Wang and Georgakakos 2007; Ogden et al. 2013). Streamflow is estimated from the Budyko curve (Budyko 1974). Values of $C N_{0.2}$ are taken from Table 9-1 in NRCS (2004a); values of $C N_{0.05}$ are computed via Equation (4).

\begin{tabular}{|c|c|c|c|c|c|c|c|}
\hline $\begin{array}{l}\text { Land } \\
\text { Cover }\end{array}$ & $\begin{array}{l}\text { Hydrol. } \\
\text { Soil } \\
\text { Group }\end{array}$ & $\begin{array}{l}\mathrm{CN}_{0.2} \\
{[\mathrm{ARC} \mathrm{I},} \\
\text { ARC III] }\end{array}$ & $\begin{array}{l}\mathrm{CN}_{0.05} \\
{[\mathrm{ARC} \mathrm{I},} \\
\text { ARC III] }\end{array}$ & $\begin{array}{l}\text { Potential } \\
\text { evapo- } \\
\text { transpiration } \\
(\mathrm{mm} / \mathrm{yr})\end{array}$ & $\begin{array}{l}\text { Streamflow } \\
(\mathrm{mm} / \mathrm{yr})\end{array}$ & $\begin{array}{l}\text { Direct runoff } \\
(\mathrm{mm} / \mathrm{yr}) \\
\text { [confidence } \\
\text { interval from } \\
\text { ARC I, III] }\end{array}$ & $\begin{array}{l}\text { Change in } \\
\text { baseflow, } \\
\text { woods to pasture } \\
\text { (mm/year) } \\
\text { [confidence } \\
\text { interval from ARC } \\
\text { I, III] }\end{array}$ \\
\hline $\begin{array}{l}\text { Woods, } \\
\text { good } \\
\text { quality }\end{array}$ & $\mathrm{B}$ & $\begin{array}{l}55 \\
{[35,74]}\end{array}$ & $42[23,64]$ & 1100 & 1710 & $20[0,150]$ & $-40[-360,120]$ \\
\hline $\begin{array}{l}\text { Pasture, } \\
\text { poor } \\
\text { quality }\end{array}$ & $\mathrm{B}$ & $\begin{array}{l}79 \\
{[62,91]}\end{array}$ & $70[49,87]$ & 900 & 1870 & $220[40,670]$ & \\
\hline $\begin{array}{l}\text { Woods, } \\
\text { good } \\
\text { quality }\end{array}$ & $\mathrm{D}$ & $\begin{array}{l}77 \\
{[59,89]}\end{array}$ & $67[46,84]$ & 1100 & 1710 & $180[30,550]$ & $-210[-490,20]$ \\
\hline $\begin{array}{l}\text { Pasture, } \\
\text { poor } \\
\text { quality }\end{array}$ & $\mathrm{D}$ & $\begin{array}{l}89 \\
{[76,96]}\end{array}$ & $84[66,94]$ & 900 & 1870 & $\begin{array}{l}550[170, \\
1200]\end{array}$ & \\
\hline
\end{tabular}


Guswa, Hamel, and Meyer

Curve number approach to estimate monthly and annual direct runoff

Figure captions

Figure 1

U.S. watersheds used in testing of the curve number approach. Gages indicated by an open circle represent the 544 watersheds used in the monthly analysis. Gages indicated by a closed circle represent the 97 watersheds used in both monthly and annual analyses.

Figure 2

Mean monthly direct runoff estimated by new approach versus observed mean monthly direct runoff for 544 U.S. watersheds. Circles represent estimates for which the actual number of rain events per month were used; pluses represent estimates that use the average number of events per month. The uncertainty envelope associated with tabulated curve numbers is given by the $\mathrm{x}$ 's.

Figure 3

Comparison of root-mean-squared error (RMSE) for estimates of monthly direct runoff from the application of the curve number method to daily rainfall data to RMSE from the new approach for 544 U.S. watersheds. Circles represent estimates using the actual number of rain events per month; pluses represent estimates that use the average number of events per month.

Figure 4

Mean annual direct runoff estimated by new approach versus observed mean annual direct runoff for 97 U.S. watersheds. Circles represent estimates using the actual number of rain events per year; pluses represent estimates that use the average number of events per year. The uncertainty envelope associated with tabulated curve numbers is given by the x's.

Figure 5

Comparison of root-mean-squared error (RMSE) in estimates of annual direct runoff from the application of the curve number method to daily rainfall data to RMSE from the new approach for 97 U.S. watersheds. Circles represent estimates using the actual number of rain events per year; pluses represent estimates that use the average number of events per year. 


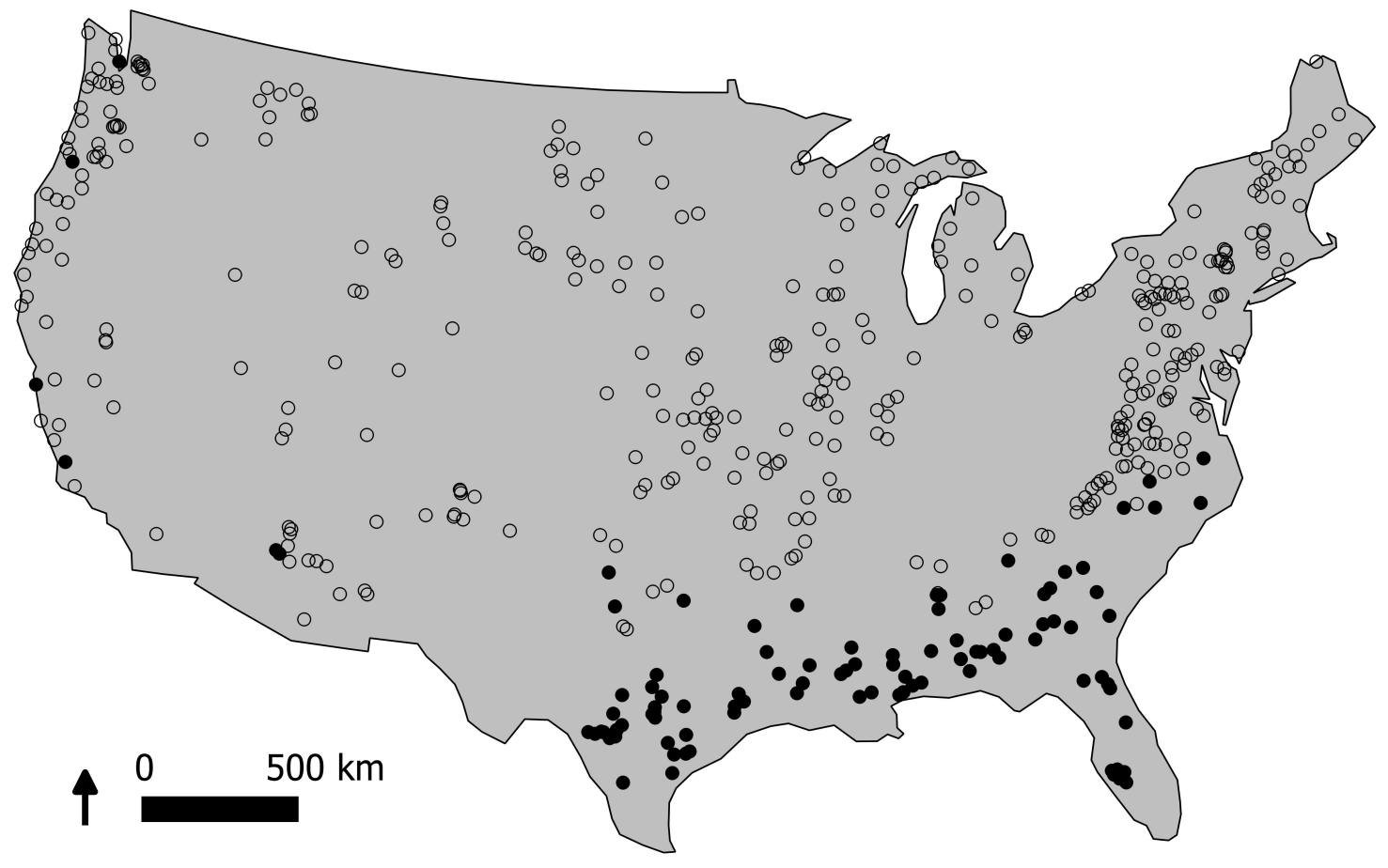




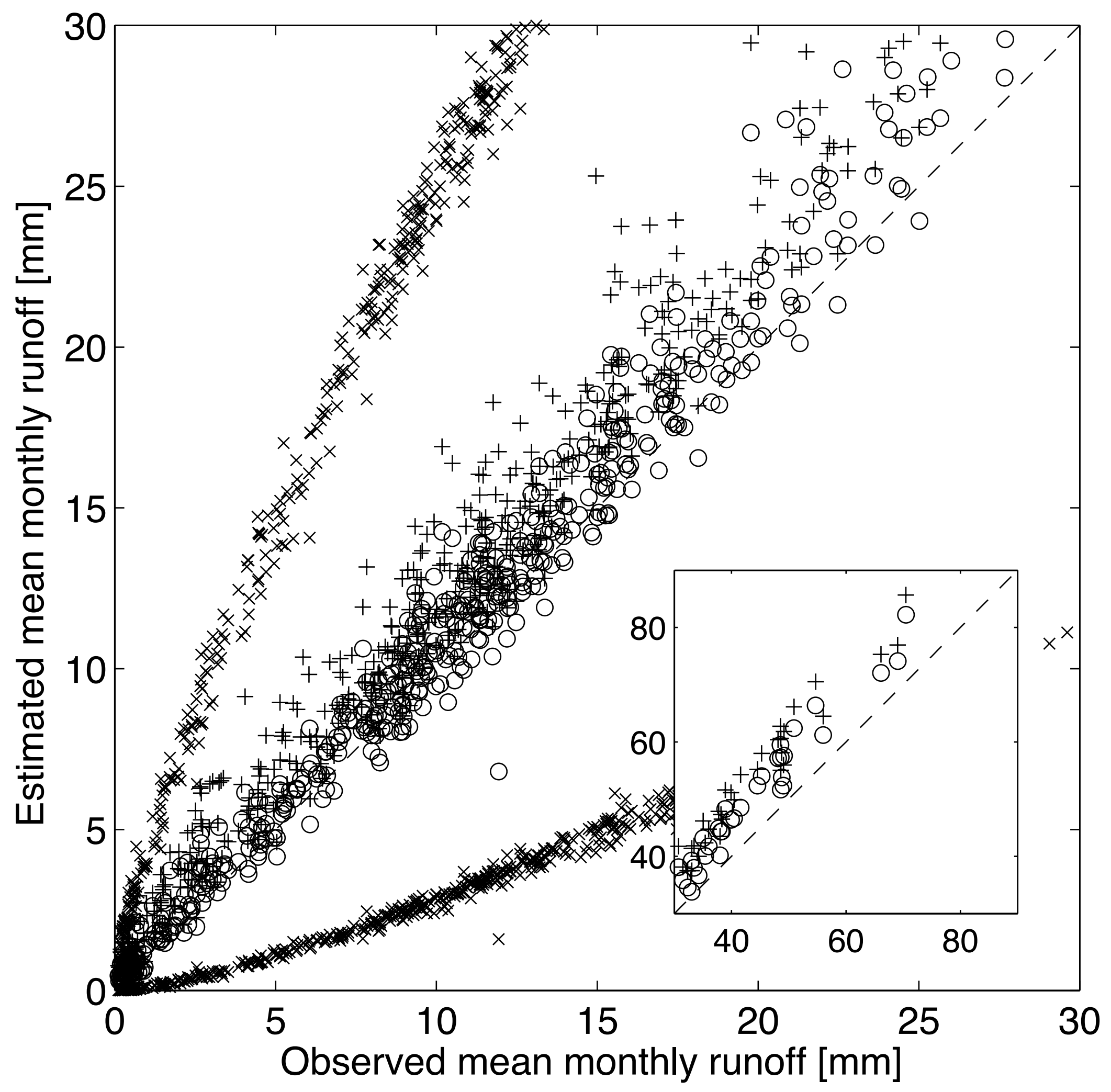




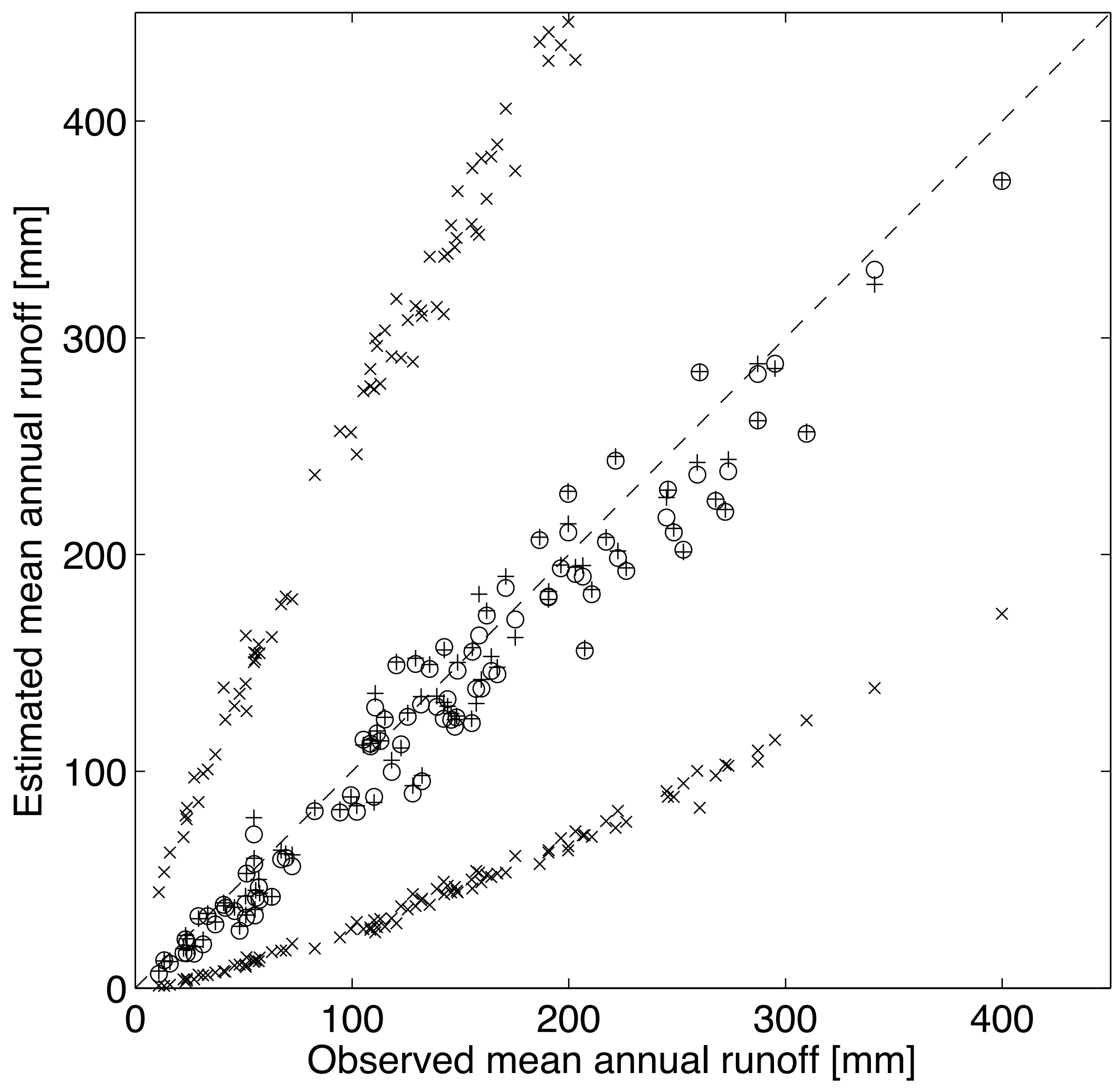




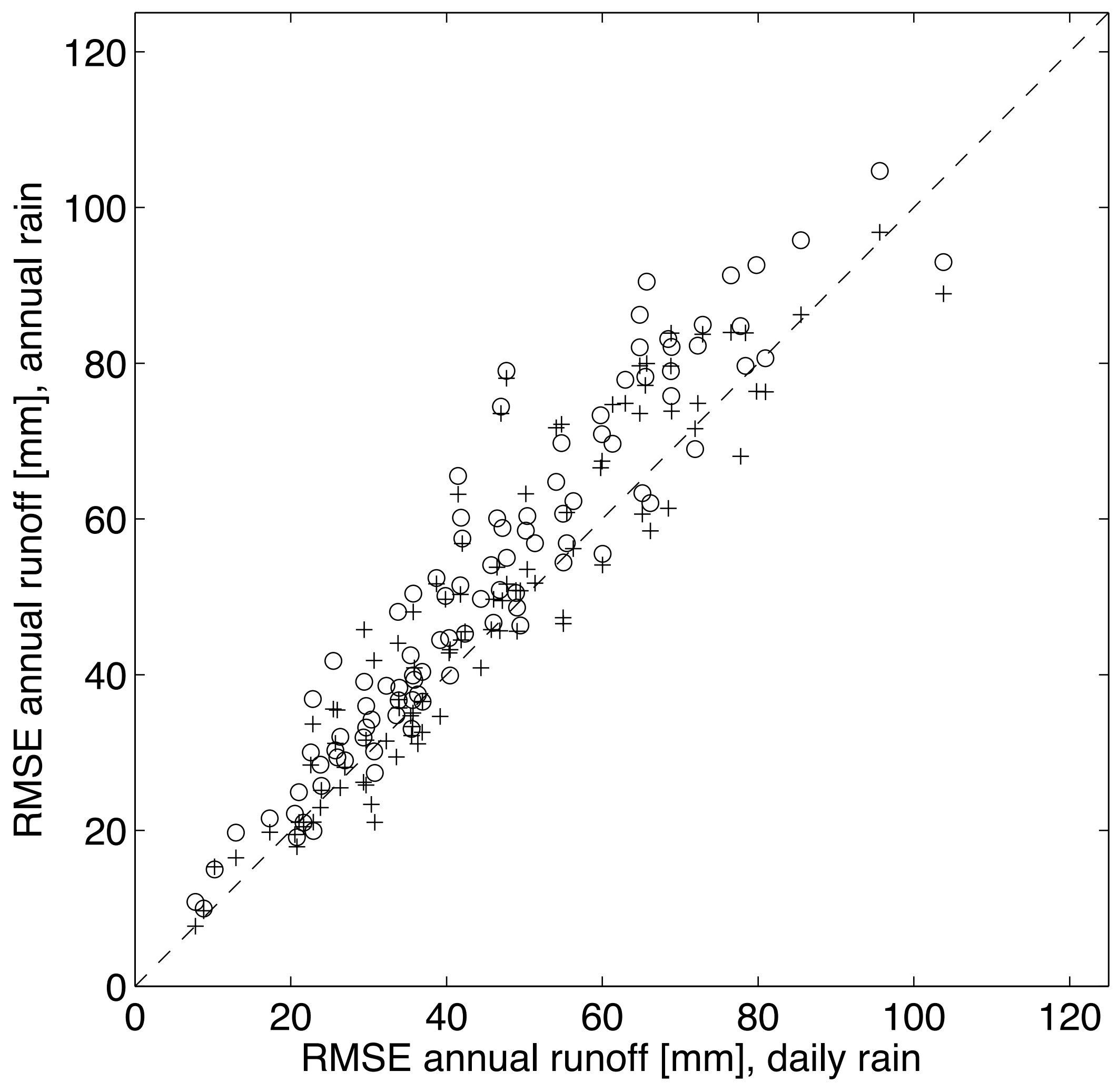


Table A1. Watersheds removed from analyses.

\begin{tabular}{|c|c|}
\hline Gaging station & Reason for removal \\
\hline $\begin{array}{l}0302108000 \\
\text { NE Cape Fear, NC }\end{array}$ & $\begin{array}{l}\text { Area and elevation in basin characteristics file do } \\
\text { not match U.S. Geolgoical Survey website or } \\
\text { information in gage information file }\end{array}$ \\
\hline $\begin{array}{l}0302310947 \\
\text { Withlacoochee River near Cumpressco, FL }\end{array}$ & $\begin{array}{l}\text { Multiple, long, discontinuous gaps in the } \\
\text { streamflow record }\end{array}$ \\
\hline $\begin{array}{l}0302381600 \\
\text { Fausett Creek near Talking Rock, GA }\end{array}$ & $\begin{array}{l}\text { Average streamflow from daily values, } \mathrm{q} \text { is greater } \\
\text { than } 150 \% \text { of reported average streamflow, } \mathrm{Q}\end{array}$ \\
\hline $\begin{array}{l}0503357350 \\
\text { Plum Creek near Bainbridge, IN }\end{array}$ & $\begin{array}{l}\text { Average streamflow from daily values, } \mathrm{q} \text {, is less } \\
\text { than } 50 \% \text { of reported average streamflow, Q }\end{array}$ \\
\hline $\begin{array}{l}0905062500 \\
\text { Wild Rice River at Twin Valley, MN }\end{array}$ & $\begin{array}{l}\text { Average streamflow from daily values, } \mathrm{q} \text { is greater } \\
\text { than } 150 \% \text { of reported average streamflow, } \mathrm{Q}\end{array}$ \\
\hline $\begin{array}{l}0905087500 \\
\text { Middle River at Argyle, MN }\end{array}$ & $\begin{array}{l}\text { Average streamflow from daily values, } \mathrm{q} \text { is greater } \\
\text { than } 150 \% \text { of reported average streamflow, } \mathrm{Q}\end{array}$ \\
\hline $\begin{array}{l}0905120500 \\
\text { Wintering River near Karlsruhe, ND }\end{array}$ & $\begin{array}{l}\text { Average streamflow from daily values, } \mathrm{q} \text {, is less } \\
\text { than } 50 \% \text { of reported average streamflow, Q }\end{array}$ \\
\hline $\begin{array}{l}1006468250 \\
\text { James River near Kensal, ND }\end{array}$ & $\begin{array}{l}\text { Average streamflow from daily values, } \mathrm{q} \text {, is less } \\
\text { than } 50 \% \text { of reported average streamflow, Q }\end{array}$ \\
\hline $\begin{array}{l}1006441500 \\
\text { Bad River near Fort Pierre, SD }\end{array}$ & Multiple long gaps in streamflow record \\
\hline $\begin{array}{l}1107067000 \\
\text { Current River at Van Buren, MO }\end{array}$ & $\begin{array}{l}\text { Area and elevation in basin_characteristics file do } \\
\text { not match U.S. Geological Survey website or } \\
\text { information in gage information file }\end{array}$ \\
\hline $\begin{array}{l}1208079600 \\
\text { Brazos River at Justiceburg, TX }\end{array}$ & $\begin{array}{l}\text { Average streamflow from daily values, } \mathrm{q} \text {, is less } \\
\text { than } 50 \% \text { of reported average streamflow, Q }\end{array}$ \\
\hline $\begin{array}{l}1509484000 \\
\text { Sabino Creek near Tucson, AZ }\end{array}$ & $\begin{array}{l}\text { Multiple extended gaps in streamflow record } \\
\text { throughout }\end{array}$ \\
\hline $\begin{array}{l}1509492400 \\
\text { East Fork White River near Apache, AZ }\end{array}$ & $\begin{array}{l}\text { Average streamflow from daily values, } \mathrm{q} \text { is greater } \\
\text { than } 150 \% \text { of reported average streamflow, } \mathrm{Q}\end{array}$ \\
\hline $\begin{array}{l}1610166430 \\
\text { West Canyon Creek near Cedar Fort, UT }\end{array}$ & $\begin{array}{l}\text { Average streamflow from daily values, } \mathrm{q} \text {, is less } \\
\text { than } 50 \% \text { of reported average streamflow, Q }\end{array}$ \\
\hline $\begin{array}{l}1610172700 \\
\text { Vernon Creek near Vernon, UT }\end{array}$ & $\begin{array}{l}\text { Average streamflow from daily values, } \mathrm{q} \text {, is less } \\
\text { than } 50 \% \text { of reported average streamflow, Q }\end{array}$ \\
\hline $\begin{array}{l}1610172800 \\
\text { South Willow Creek near Grantsville, UT }\end{array}$ & $\begin{array}{l}\text { Average streamflow from daily values, } \mathrm{q} \text {, is less } \\
\text { than } 50 \% \text { of reported average streamflow, Q }\end{array}$ \\
\hline $\begin{array}{l}1610242000 \\
\text { Coal Creek near Cedar City, UT }\end{array}$ & $\begin{array}{l}\text { Average streamflow from daily values, } \mathrm{q} \text {, is less } \\
\text { than } 50 \% \text { of reported average streamflow, Q }\end{array}$ \\
\hline $\begin{array}{l}1610249300 \\
\text { South Twin River nr Round Mountain, NV }\end{array}$ & $\begin{array}{l}\text { Average streamflow from daily values, } \mathrm{q} \text {, is less } \\
\text { than } 50 \% \text { of reported average streamflow, Q }\end{array}$ \\
\hline $\begin{array}{l}1810259200 \\
\text { Deep Creek near Palm Desert, CA }\end{array}$ & $\begin{array}{l}\text { Average streamflow from daily values, } \mathrm{q} \text {, is less } \\
\text { than } 50 \% \text { of reported average streamflow, Q }\end{array}$ \\
\hline $\begin{array}{l}1810263500 \\
\text { Big Rock Creek near Valyermo, CA }\end{array}$ & $\begin{array}{l}\text { Average streamflow from daily values, } \mathrm{q} \text {, is less } \\
\text { than } 50 \% \text { of reported average streamflow, Q }\end{array}$ \\
\hline 1811253310 & Average streamflow from daily values, $\mathrm{q}$, is less \\
\hline
\end{tabular}




\begin{tabular}{|c|c|}
\hline Cantua Creek near Cantua Creek, CA & than $50 \%$ of reported average streamflow, Q \\
\hline $\begin{array}{l}1712040500 \\
\text { Queets River nr Clearwater, WA }\end{array}$ & Runoff ratio is greater than $1 ; q$ is greater than $p$ \\
\hline $\begin{array}{l}1712041200 \\
\text { Hoh River nr Forks, WA }\end{array}$ & Runoff ratio is greater than $1 ; q$ is greater than $p$ \\
\hline $\begin{array}{l}1712056500 \\
\text { NF Skokomish River near Hoodsport, WA }\end{array}$ & Runoff ratio is greater than $1 ; q$ is greater than $p$ \\
\hline $\begin{array}{l}1712147500 \\
\text { NF Tolt River near Carnation, WA }\end{array}$ & $\begin{array}{l}\text { Runoff ratio is greater than } 1 ; q \text { is greater than } p \\
\text { and } Q \text { is greater than } P\end{array}$ \\
\hline $\begin{array}{l}1712147600 \\
\text { SF Tolt River near Index, WA }\end{array}$ & Runoff ratio greater than 1 ; $Q$ is greater than $P$ \\
\hline $\begin{array}{l}1712167000 \\
\text { NF Stillaguamish River near Arlington, } \\
\text { WA }\end{array}$ & $\begin{array}{l}\text { Runoff ratio greater than } 1 ; \mathrm{q} \text { is greater than } \mathrm{p} \text { and } \\
\mathrm{Q} \text { is greater than } \mathrm{P}\end{array}$ \\
\hline $\begin{array}{l}1712186000 \\
\text { Sauk River near Darrington, WA }\end{array}$ & $\begin{array}{l}\text { Runoff ratio greater than } 1 ; \mathrm{q} \text { is greater than } \mathrm{p} \text { and } \\
\mathrm{Q} \text { is greater than } \mathrm{P}\end{array}$ \\
\hline $\begin{array}{l}1714158500 \\
\text { McKenzie River near Clear Lake, OR }\end{array}$ & Runoff ratio greater than $1 ; q$ is greater than $p$ \\
\hline $\begin{array}{l}1714400000 \\
\text { Brookings, OR }\end{array}$ & $\begin{array}{l}\text { Runoff ratio greater than } 1 ; \mathrm{q} \text { is greater than } \mathrm{p} \text { and } \\
\mathrm{Q} \text { is greater than } \mathrm{P}\end{array}$ \\
\hline
\end{tabular}

Table A2. Modified streamflow records.

\begin{tabular}{|c|c|c|}
\hline Gaging station & Issue & Resolution \\
\hline $\begin{array}{l}0302051000 \\
\text { North Meherrin River } \\
\text { near Lunenburg, VA }\end{array}$ & $\begin{array}{l}\text { Gap in streamflow record from } \\
10 / 1 / 1980 \text { through } 9 / 30 / 1981\end{array}$ & $\begin{array}{l}\text { Use streamflow from } 10 / 1 / 1981 \\
\text { through } 12 / 31 / 2010\end{array}$ \\
\hline $\begin{array}{l}0302235200 \\
\text { Blackwater Creek near } \\
\text { Cassia, FL }\end{array}$ & $\begin{array}{l}\text { Large gaps in streamflow record } \\
\text { from } 12 / 1 / 1980 \text { through } 6 / 9 / 1985\end{array}$ & $\begin{array}{l}\text { Use streamflow from } 7 / 1 / 1985 \\
\text { through } 12 / 31 / 2010\end{array}$ \\
\hline $\begin{array}{l}0302408540 \\
\text { Hatchet Creek below } \\
\text { Rockford, AL }\end{array}$ & $\begin{array}{l}\text { Gap in streamflow record from } \\
9 / 25 / 1980 \text { through } 9 / 30 / 1980\end{array}$ & $\begin{array}{l}\text { Use streamflow from 10/1/1980 } \\
\text { through } 12 / 31 / 2010\end{array}$ \\
\hline $\begin{array}{l}0302464146 \\
\text { Turkey Creek near } \\
\text { Tuscaloosa, AL }\end{array}$ & $\begin{array}{l}\text { Gap in streamflow record from } \\
\text { 10/1/1984 through } 9 / 30 / 1986 ; \\
\text { recorded as zeroes }\end{array}$ & $\begin{array}{l}\text { Use streamflow from } 10 / 1 / 1986 \\
\text { through } 12 / 31 / 2010 \text { only }\end{array}$ \\
\hline $\begin{array}{l}0503066000 \\
\text { Blackwater River at } \\
\text { Davis, WV }\end{array}$ & $\begin{array}{l}\text { Gap in streamflow record from } \\
10 / 1 / 1991 \text { through } 9 / 30 / 1992\end{array}$ & $\begin{array}{l}\text { Use streamflow from } 10 / 1 / 1992 \\
\text { through } 12 / 31 / 2010 \text { only }\end{array}$ \\
\hline $\begin{array}{l}0503159540 \\
\text { Shade River near } \\
\text { Chester, OH }\end{array}$ & $\begin{array}{l}\text { Some estimated streamflow; no } \\
\text { significant gaps found }\end{array}$ & Use data as are \\
\hline $\begin{array}{l}0503161000 \\
\text { South Fork New River }\end{array}$ & $\begin{array}{l}\text { Some estimated streamflow; no } \\
\text { significant gaps found }\end{array}$ & Use data as are \\
\hline
\end{tabular}




\begin{tabular}{|c|c|c|}
\hline near Jefferson, NC & & \\
\hline $\begin{array}{l}0503187500 \\
\text { Cranberry Creek near } \\
\text { Richmond, WV } \\
\end{array}$ & $\begin{array}{l}\text { Gap in streamflow record from } \\
10 / 1 / 1982 \text { through } 2 / 29 / 1984\end{array}$ & $\begin{array}{l}\text { Use streamflow from } 3 / 1 / 1984 \\
\text { through } 12 / 31 / 2010 \text { only }\end{array}$ \\
\hline $\begin{array}{l}0503281100 \\
\text { Goose Creek at } \\
\text { Manchester, KY }\end{array}$ & $\begin{array}{l}\text { Gap in streamflow record from } \\
10 / 1 / 2000 \text { through } 9 / 30 / 2001 \text { and } \\
10 / 1 / 2003 \text { through } 9 / 30 / 2006\end{array}$ & $\begin{array}{l}\text { Use streamflow from } 1 / 1 / 980 \\
\text { through } 9 / 30 / 2000 \text { only }\end{array}$ \\
\hline $\begin{array}{l}0503300400 \\
\text { Beech Fork at Maud, } \\
\text { KY }\end{array}$ & $\begin{array}{l}\text { Gap in streamflow record from } \\
5 / 3 / 2010 \text { through } 6 / 13 / 2010\end{array}$ & $\begin{array}{l}\text { Use streamflow from } 1 / 1 / 1980 \\
\text { through } 4 / 30 / 2010 \text { only }\end{array}$ \\
\hline $\begin{array}{l}0603450000 \\
\text { Beetree Creek near } \\
\text { Swannanoa, NC }\end{array}$ & $\begin{array}{l}\text { Gap in streamflow record from } \\
10 / 1 / 1981 \text { through } 8 / 28 / 1985\end{array}$ & $\begin{array}{l}\text { Use streamflow from } 9 / 1 / 1985 \\
\text { through } 12 / 31 / 2010\end{array}$ \\
\hline $\begin{array}{l}0905062500 \\
\text { Wild Rice River at } \\
\text { Twin Valley, MN }\end{array}$ & $\begin{array}{l}\text { Gap in streamflow record from } \\
10 / 21 / 1983 \text { through } 9 / 13 / 1989\end{array}$ & $\begin{array}{l}\text { Use streamflow from 10/1/1989 } \\
\text { through } 12 / 31 / 2010\end{array}$ \\
\hline $\begin{array}{l}1006037500 \\
\text { Madison River near } \\
\text { West Yellowstone, MT }\end{array}$ & $\begin{array}{l}\text { Gap in streamflow record from } \\
10 / 1 / 1986 \text { through } 9 / 30 / 1988\end{array}$ & $\begin{array}{l}\text { Use streamflow from } 10 / 1 / 1988 \\
\text { through } 12 / 31 / 2010 \text { only }\end{array}$ \\
\hline $\begin{array}{l}1006043500 \\
\text { Gallatin River near } \\
\text { Gallatin Gateway, MT }\end{array}$ & $\begin{array}{l}\text { Gap in streamflow record from } \\
10 / 1 / 1981 \text { through } 9 / 30 / 1984\end{array}$ & $\begin{array}{l}\text { Use streamflow from } 10 / 1 / 1984 \\
\text { through } 12 / 31 / 2010 \text { only }\end{array}$ \\
\hline $\begin{array}{l}1006188000 \\
\text { Lamar River near } \\
\text { Tower Falls Ranger } \\
\text { Station, Yellowstone } \\
\text { National Park }\end{array}$ & $\begin{array}{l}\text { Gap in streamflow record from } \\
10 / 1 / 1985 \text { through } 4 / 30 / 1986 \text { and } \\
\text { from } 10 / 1 / 1986 \text { through } 8 / 31 / 1988\end{array}$ & $\begin{array}{l}\text { Use streamflow from } 9 / 1 / 1988 \\
\text { through } 12 / 31 / 2010 \text { only }\end{array}$ \\
\hline $\begin{array}{l}0807290650 \\
\text { Bayou Pierre near } \\
\text { Willows, MS } \\
\end{array}$ & $\begin{array}{l}\text { Extended gaps in record between } \\
10 / 1 / 2009 \text { and } 12 / 31 / 2010\end{array}$ & $\begin{array}{l}\text { Use streamflow from } 1 / 1 / 1980 \\
\text { through } 9 / 30 / 2009\end{array}$ \\
\hline $\begin{array}{l}0807295000 \\
\text { Buffalo River near } \\
\text { Woodville, MS }\end{array}$ & $\begin{array}{l}\text { Extended gaps in record between } \\
10 / 1 / 2009 \text { through } 12 / 31 / 2010\end{array}$ & $\begin{array}{l}\text { Use streamflow from } 1 / 1 / 1980 \\
\text { through } 9 / 30 / 2009\end{array}$ \\
\hline $\begin{array}{l}0807376000 \\
\text { Tickfaw River at } \\
\text { Holden, LA }\end{array}$ & $\begin{array}{l}\text { Gap in streamflow record from } \\
10 / 1 / 1988 \text { through } 9 / 30 / 1989\end{array}$ & $\begin{array}{l}\text { Use streamflow from } 10 / 1 / 1989 \\
\text { through } 12 / 31 / 2010 \text { only }\end{array}$ \\
\hline $\begin{array}{l}1208025500 \\
\text { Bayou Toro near Toro, } \\
\text { LA }\end{array}$ & $\begin{array}{l}\text { Gap in streamflow record from } \\
10 / 1 / 1986 \text { through } 9 / 30 / 1988\end{array}$ & $\begin{array}{l}\text { Use streamflow from } 10 / 1 / 1988 \\
\text { through } 12 / 31 / 2010 \text { only }\end{array}$ \\
\hline $\begin{array}{l}1208155200 \\
\text { Barton Creek near Oak } \\
\text { Hill, TX }\end{array}$ & $\begin{array}{l}\text { Gap in streamflow record from } \\
10 / 15 / 1982 \text { through } 1 / 29 / 1989 ; \text { also } \\
\text { multiple periods of zero streamflow }\end{array}$ & $\begin{array}{l}\text { Use streamflow from } 2 / 1 / 1989 \\
\text { through } 12 / 31 / 2010\end{array}$ \\
\hline $\begin{array}{l}1509497800 \\
\text { Cibecue Creek near } \\
\text { Chysotile, AZ }\end{array}$ & $\begin{array}{l}\text { Gap in streamflow record from } \\
10 / 1 / 2009 \text { through } 6 / 13 / 2010\end{array}$ & $\begin{array}{l}\text { Use streamflow from } 1 / 1 / 1980 \\
\text { through } 9 / 30 / 2009 \text { only }\end{array}$ \\
\hline 1509505200 & Gap in streamflow record from & Use streamflow from $10 / 1 / 1988$ \\
\hline
\end{tabular}




\begin{tabular}{|c|c|c|}
\hline $\begin{array}{l}\text { Wet Beaver Creek near } \\
\text { Rimrock, AZ }\end{array}$ & $\begin{array}{l}10 / 1 / 1982 \text { through } 9 / 30 / 1985 \text { and } \\
10 / 1 / 1987 \text { through } 9 / 30 / 1988\end{array}$ & through $12 / 31 / 2010$ only \\
\hline $\begin{array}{l}1712025000 \\
\text { Newaukum River near } \\
\text { Chehalis, WA }\end{array}$ & $\begin{array}{l}\text { Gap in streamflow record from } \\
10 / 1 / 1981 \text { through } 9 / 30 / 1982\end{array}$ & $\begin{array}{l}\text { Use streamflow from } 10 / 1 / 1982 \\
\text { through } 12 / 31 / 2010 \text { only }\end{array}$ \\
\hline $\begin{array}{l}1712043000 \\
\text { Calawah River near } \\
\text { Forks, WA }\end{array}$ & $\begin{array}{l}\text { Gap in streamflow record from } \\
10 / 1 / 1980 \text { through } 2 / 29 / 1984\end{array}$ & $\begin{array}{l}\text { Use streamflow from } 3 / 1 / 1984 \\
\text { through } 12 / 31 / 2010\end{array}$ \\
\hline $\begin{array}{l}1712141300 \\
\text { Middle Fork } \\
\text { Snoqualmie River near } \\
\text { Tanner, WA }\end{array}$ & $\begin{array}{l}\text { Gap in streamflow record from } \\
10 / 1 / 1991 \text { through } 9 / 30 / 1992\end{array}$ & $\begin{array}{l}\text { Use streamflow from } 10 / 1 / 1992 \\
\text { through } 12 / 31 / 2010 \text { only }\end{array}$ \\
\hline $\begin{array}{l}1712374250 \\
\text { Mill Creek near } \\
\text { Niarada, MT }\end{array}$ & $\begin{array}{l}\text { Gap in streamflow record from } \\
9 / 1 / 1982 \text { through } 9 / 30 / 1982\end{array}$ & $\begin{array}{l}\text { Use streamflow from 10/1/1982 } \\
\text { through } 12 / 31 / 2010\end{array}$ \\
\hline $\begin{array}{l}1713310700 \\
\text { South Fork Salmon } \\
\text { River near Krassel } \\
\text { Ranger Station, ID }\end{array}$ & $\begin{array}{l}\text { Gap in streamflow record from } \\
10 / 1 / 1982 \text { through } 3 / 31 / 1985 \text {, } \\
10 / 1 / 1986 \text { through } 1 / 31 / 1989 \text {, }\end{array}$ & $\begin{array}{l}\text { Use streamflow from } 2 / 1 / 1989 \\
\text { through } 12 / 31 / 2010\end{array}$ \\
\hline
\end{tabular}

